\title{
Analisis Perencanaan Strategis, Rencana Strategis Dan Manajemen Strategis STAIN Curup 2015-2019
}

\author{
Jumira Warlizasusi \\ Sekolah Tinggi Agama Islam Negeri (STAIN) Curup \\ jumira.ifnaldi@gmail.com
}

\begin{abstract}
The strategics plan is a guideline for a short plan.the strategic plan isn't as boly as the boly book till it couldn't be changed.depend on the route record of this strategics plan, it can be evaluated.for it implementation, $R K A$ oftenly not according to the strategic plan. even it found that $R K A$ is more priority than the strategic plan.so it considered like useless thing and it only needed if it necessary. component of agency performance appraisal, and the proo of the documentation for evidence it's realistic as same as planned (has a track record exist). Arranging the strategic plan of STAIN Curup process during 2015-2019 it started with mapping the activities until 2014. besides of this situation, it could be known all of the troubles and the defiances which it has influence the functions and the main assignment. more over, it needed the analysis about the influence of strategic environment which it involved. even it direct or indirect, with main assignment or a function, although it internal or external. the influence of internal strategic would be trasformated into the strength and the weakness, so the influence of external strategic will be transformating into the opportunities and the treath. By considering of this influence environment strategic change, it propose the rules of wisdom to reach the performance's target inside arranging strategic plan of STAIN Curup 2015-2019. to clear the main assignment and it function's way, the vision it would be formulated and described into yhe mission side.based on vision and mission, it formulated the purpose, target, priority,strategy and the wisdom's way. The strategic plan of STAIN Curup in 2015-2019 need to analyzed for get the understanding complex has been reached. began from analyzing the strategic planning, strategic plan and strategic management, analyzing design of organization as the initial supply to plan the strategic, analyze of building the capability of natural resource and evolving structural organization, analyze the payment and suspension organization system, analyze of matching the internal process and learn process in an organization,analyze centralization and decentralization inside strategic management,analyze the strategic when control and analyzing management change and organization learners.
\end{abstract}

Keywords: Strategic Planning, Strategics Plan, Strategic Management

\begin{abstract}
Abstrak : Renstra merupakan pedoman bagi perencanaan jangka pendek. namun demikian, Renstra bukanlah kitab suci yang tidak boleh diubah isinya. Renstra dalam perjalanannya dapat dievaluasi. Pada implementasinya, seringkeali dalam penyusunan RKA tidak mengacu pada Renstra. Babkan dapat dikatakan babwa RKA menempati urutan pertama sedangkan Renstra bukan prioritas. Sebingga keberadaan Renstra banya menjadi dokumen pajangan yang dicari jika dibutubkan kehadiran fisiknya, komponen penilaian kinerja instansi, serta dokumentasi perencanaan untuk pembuktian suatu proyek tidak fiktif dan sesuai rencana (ada track record-nya). Proses penyusunan Rencana Strategis STAIN Curup tahun 2015-2019 diawali dengan melakukan pemetaan kegiatan sampai tahun 2014.. Disamping itu perlu dicermati permasalahan dan tantangan yang berpengaruh terhadap tugas pokok dan fungsi. Selain itu diperlukan analisis terhadap pengaruh lingkungan strategis yang terkait, baik langsung maupun tidak langsung dengan tugas pokok dan fungsi, baik internal maupun eksternal. Pengaruh strategis internal akan diformulasikan dalam bentuk kekuatan (strength) dan kelemahan (weakness) sedangkean pengarub strategis eksternal akan diformulasikan dalam bentuk peluang (opportunity) dan ancaman (treath). Dengan mempertimbangkan pengarub perubahan lingkungan strategis tersebut maka di dalam penyusunan Rencana Strategis STAIN Curup 2015-2019 dirumuskan langkahlangkeah kebijakan lanjut dalam mencapai target kinerja. Dalam rangke memperjelas arah tugas pokok dan fungsi akan dirumuskan visi yang dijabarkan lanjut ke dalam Misi. Berdasarkan visi dan misi diformulasikan tujuan, sasaran, prioritas, strategi dan arah kebijakan pembangunan. Renstra STAIN Curup 2015-2019 perlu dianalisis guna mendapatkan pemahaman yang lengkap yaitu dengan menganalisis perencanaan strategis, rencana strategis dan manajemen strategis, analisis desain organisasi sebagai modal awal perencanaan strategis, analisis membangun kapabilitas sumber daya dan mengembangkan struktur organisasi, analisis pembiayaan dan sistem penyangga organisasi, analisis membangun kultur organisasi, pemimpin strategis dan perannya, analisis menyelaraskan proses internal dan proses belajar dalam organisasi, analisis sentralisasi dan desentralisasi dalam
\end{abstract}

TADBIR : Jurnal Studi Manajemen Pendidikan vol. 2, no. 2, Desember 2018 STAIN Curup - Bengkulu | p-ISSN 2580-3581; e-ISSN 2580-5037 
manajemen strategis, analisis strategi dalam melaksanakan control, dan menganalisis manajemen perubahan dan organisasi pembelajar.

Keyword: Perencanaan Strategis, Renstra, Manajemen Strategis

\section{Pendahuluan}

Secara garis besar terdapat lima tugas manajerial yang saling berkaitan, yaitu: menetapkan visi strategis tentang pendidikan masa depan berdasarkan konstitusi serta latar budaya dan kemajuan teknologi; melakukan penjabaran dan trasformasi visi menjadi tujuan dan sasaran, menetapkan strategi untuk mencapai tujuan, melaksanakan strategi yang dipilih dengan menggunakan kriteria efektif dan efisien, dan melakukan evaluasi kinerja serta melakukan penyesuaian dari hasil evaluasi.

STAIN Curup yang merupakan Perguruan Tinggi Agama Islam Negeri memiliki dokumen Rencana Strategis tahun 2015-2019 sehingga dapat dijadikan bahan observasi guna memberikan pemahaman lebih lanjut mengenai proses perencanaan stratejik.

\section{Analisis Perencanaan Strategis, Rencana Strategis Dan Manajemen Strategis Stain Curup 2015-2019}

1. Konsep Perencanaan Strategis, Rencana Strategis dan Manajemen Strategis

Perencanaan strategis digunakan untuk mencapai keuntungan kompetitif dan untuk mengintegrasikan semua area fungsional lembaga dengan memfasilitasi komunikasi antara seluruh level manajer.

Rencana strategis adalah dokumen yang digunakan untuk berkomunikasi dengan organisasi, tujuan organisasi dan aksi yang diperlukan untuk meraih tujuan tersebut dan segala elemen kritis lain yang dibangun selama mengolah perencanaan. Manajemen strategis adalah kumpulan menyeluruh dari aktivitas dan proses yang sedang berjalan yang digunakan organisasi untuk secara sistematis mengkoordinasikan dan menyelaraskan sumber daya dan aksi-aksi dengan misi, visi, strategi melalui sebuah organisasi. Aktivitas manajemen strategis mengubah bentuk dari rencana statis menjadi sebuah sistem yang menyediakan kinerja strategi dan memberikan umpan balik untuk pengambilan keputusan serta memungkinkan rencana bisa terlibat dan tumbuh sebagai persyaratan dan perubahan keadaan lainnya. Eksekusi strategi pada dasarnya sinonim manajemen strategi dan jumlah sistematik implementasi dari strategi.

Manajemen strategis adalah proses berkelanjutan dari analisis stratejik, penciptaan strategi, impelentasi dan monitoring, yang digunakan oleh perusahaan dengan tujuan untuk meraih dan mempertahankan keuntungan kompetitif. Manajemen strategis bukanlah tentang meramalkan masa depan, namun tentang mempersiapkan untuk masa depan dan mengetahui langkahlangkah apa yang pasti akan diambil perusahaan untuk mengimplementasikan rencana strategisnya dan mencapai keuntungan kompetitif (Blatstein, 2012). 
Komponen utama proses perencanaan strategi dapat digambarkan sebagai berikut :

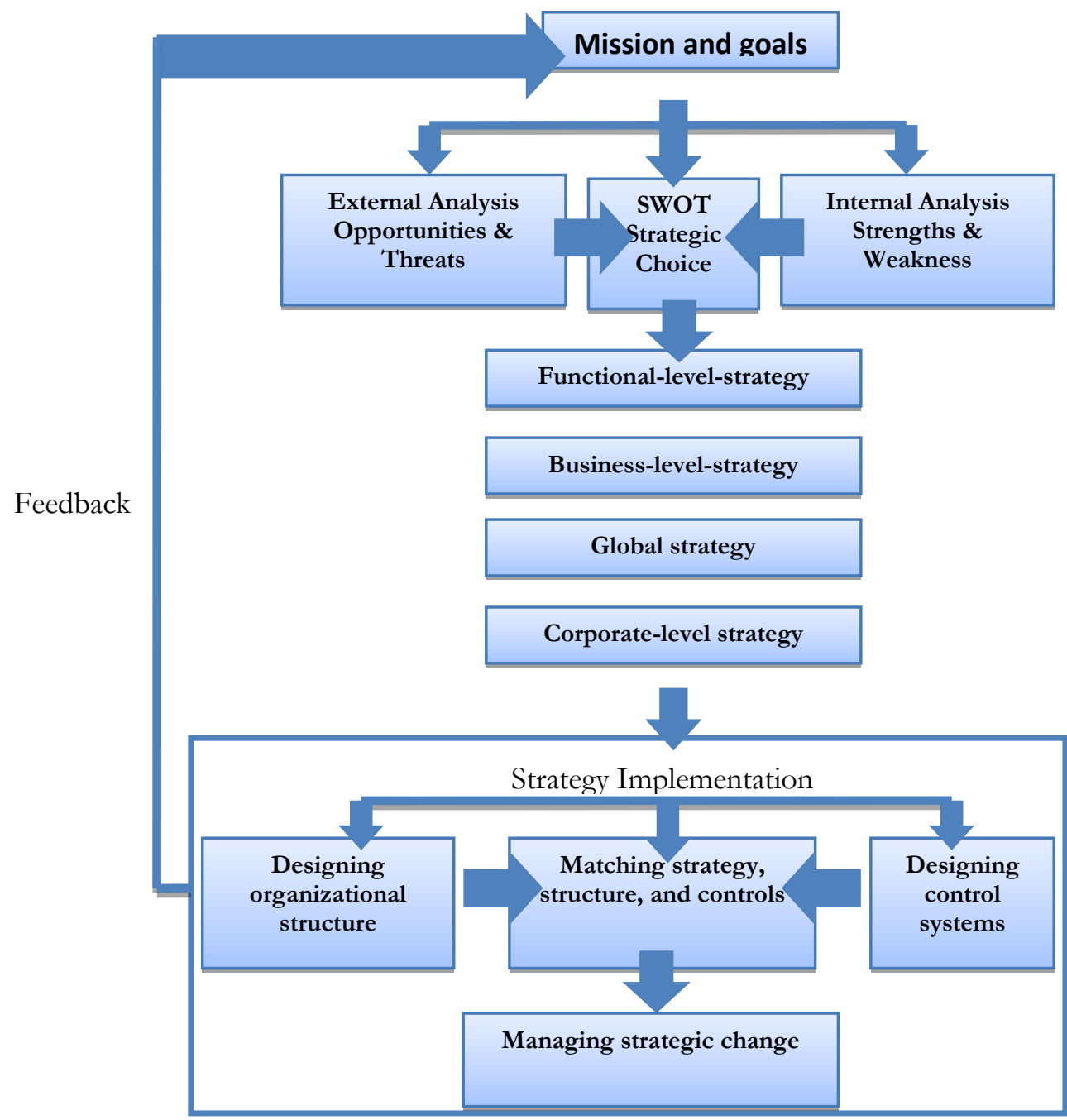

Gambar 1.1 Komponen Utama Proses Perencanaan Strategis

\section{Proses Perencanaan Strategis STAIN Curup}

Penyusunan Rencana Strategis STAIN Curup tahun 2015-2019 didasarkan secara hierarkis pada Tahapan Rencana Pembangunan Nasional yaitu

Rencana Pembangunan Pendidikan Nasional Jangka Panjang (RPPNJP) 2015-2025, dan Rencana Strategis (Renstra) Pendidikan Islam Kementerian Agama 2010-2014.

Dalam rangka untuk mengimplementasikan amanat UUD 45, maka telah disahkan UU RI Nomor 20 Tahun 2003 tentang "Sistem Pendidikan Nasional". 
Dalam UU tersebut, tujuan pendidikan nasional adalah untuk mengembangkan potensi peserta didik agar menjadi manusia yang beriman dan bertaqwa kepada Tuhan Yang Maha Esa, berakhlak mulia, sehat, berilmu, cakap, kreatif, mandiri dan menjadi warga negara yang demokratis serta bertanggung jawab. Untuk mencapai tujuan pendidikan nasional tersebut, pengembangan pendidikan tinggi di Indonesia bertumpu pada tiga pilar utama: a). kontribusi perguruan tinggi pada peningkatan daya saing bangsa (nation competitiveness), b). Pemberian otonomi dan desentralisasi wewenang dan tanggung jawab kepada perguruan tinggi (autonomy), c). penciptaan kesehatan organisasi internal perguruan tinggi (organizational healtb). Ketiga kebijakan dasar (basic policy) tersebut, secara keseluruhan mengarah pada strategi pengembangan perguruan tinggi yang lebih mandiri, mampu menghasilkan produk-produk (outputs and outcomes) yang secara nyata dapat memberikan kontribusi terhadap peningkatan kecerdasan, kemandirian dan daya saing bangsa. Hal ini sejalan dengan visi dan misi Rencana Strategis (Renstra) Pendidikan Islam Kementerian Agama 2015-2019, yaitu peningkatan mutu relevansi, dan daya saing pendidikan Islam.

Renstra merupakan pedoman bagi perencanaan jangka pendek . namun demikian, Renstra bukanlah kitab suci yang tidak boleh diubah isinya. Renstra dalam perjalanannya dapat dievaluasi. Pada implementasinya, seringkali dalam penyusunan RKA tidak mengacu pada Renstra. Bahkan dapat dikatakan bahwa RKA menempati urutan pertama sedangkan Renstra bukan prioritas. Sehingga keberadaan Renstra hanya menjadi dokumen pajangan yang dicari jika dibutuhkan kehadiran fisiknya, komponen penilaian kinerja instansi, serta dokumentasi perencanaan untuk pembuktian suatu proyek tidak fiktif dan sesuai rencana (ada track record-nya).

\section{Kerangka Pikir Perencanaan Strategis}

Proses penyusunan Rencana Strategis STAIN Curup tahun 2015-2019 diawali dengan melakukan pemetaan kegiatan sampai tahun 2014.. Disamping itu perlu dicermati permasalahan dan tantangan yang berpengaruh terhadap tugas pokok dan fungsi. Selain itu diperlukan analisis terhadap pengaruh lingkungan strategis yang terkait, baik langsung maupun tidak langsung dengan tugas pokok dan fungsi, baik internal maupun eksternal. Pengaruh strategis internal akan diformulasikan dalam bentuk kekuatan (strength) dan kelemahan (weakness) sedangkan pengaruh strategis eksternal akan diformulasikan dalam bentuk peluang (opportunity) dan ancaman (treath). Dengan mempertimbangkan pengaruh perubahan lingkungan strategis tersebut maka di dalam penyusunan Rencana Strategis STAIN Curup 2015-2019 akan dirumuskan langkah-langkah kebijakan lanjut dalam mencapai target kinerja.Dalam rangka memperjelas arah tugas pokok dan fungsi akan dirumuskan visi yang dijabarkan lanjut ke dalam Misi. Berdasarkan visi dan misi diformulasikan tujuan, sasaran, prioritas, strategi dan arah kebijakan pembangunan. Kerangka pikir penyusunan Rencana Strategis 
STAIN Curup dapat dijelaskan pada gambar 1.2. Bila dibandingkan dengan alur proses perencanaan strategis di dalam buku Strategic Management, Hills, maka terlihat perbedaan dengan kerangka pikir penyusunan Renstra STAIN Curup 2015-2019. Perencanaan strategis STAIN Curup bukan merupakan proses yang berkelanjutan karena tidak adanya feedback. Evaluasi dan kontrol juga tidak ada dalam diagram 1.2.

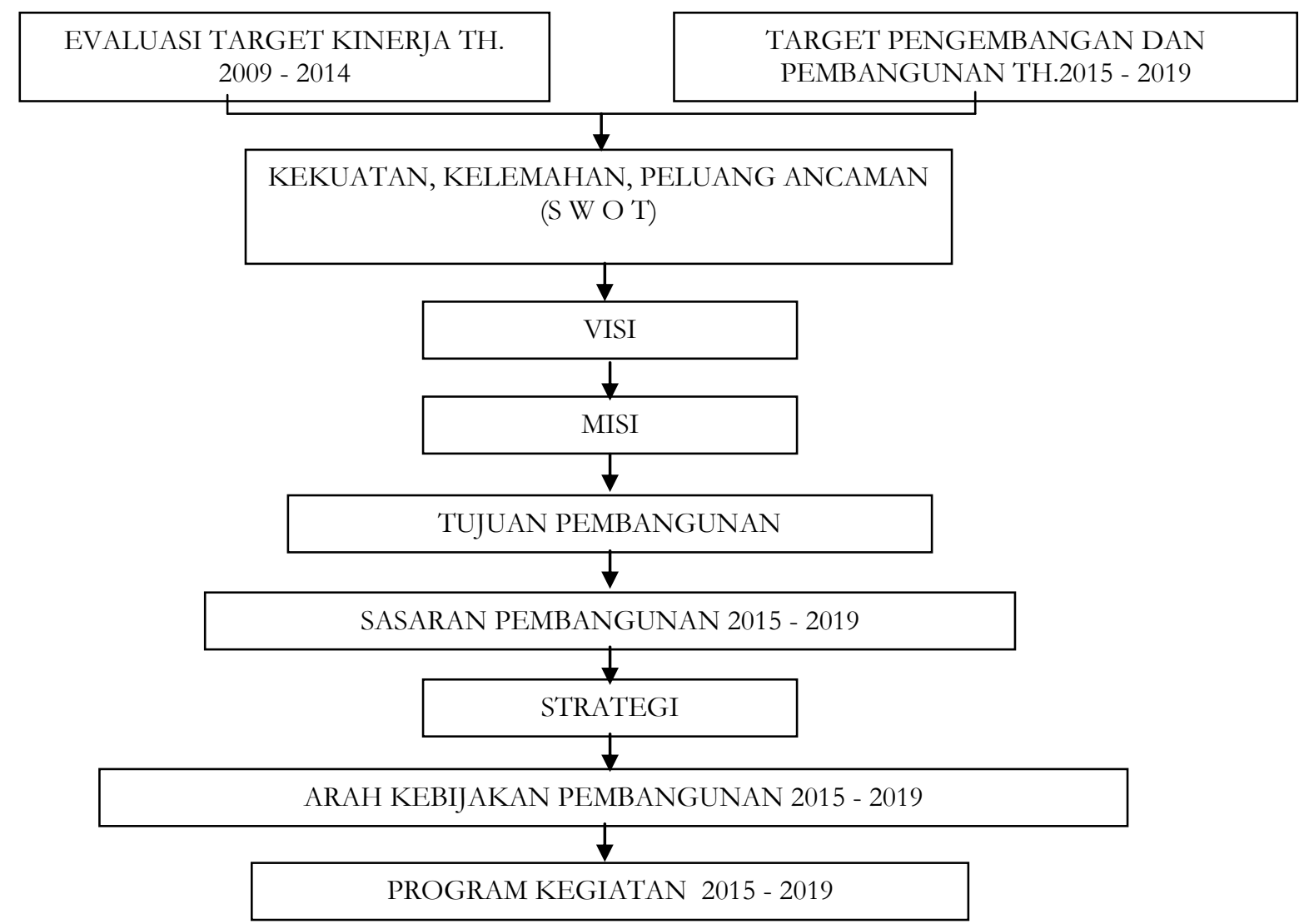

Skema 1.2. .Kerangka Pikir Penyusunan Rencana Strategis STAIN Curup

4. Analisis SWOT pada Rencana Strategis 2015-2019

Dalam dokumen Renstra Tahun 2015-2019, sudah dilakukan analisis SWOT yang merupakan hasil brainstorming terhadap faktor-faktor internal dan eksternal yang dapat mempengaruhi keberhasilan visi dan misi serta kinerja STAIN Curup, diperoleh bahwa faktor-faktor internal dan eksternal tersebut secara singkat disajikan pada tabel 2.1 . 
Tabel 2.1

Identifikasi Faktor-Faktor Internal dan Eksternal

\begin{tabular}{|c|c|c|c|}
\hline \multicolumn{4}{|c|}{ FAKTOR INTERNAL } \\
\hline No. & Kekuatan (Strengths) & No. & Kelemahan (Weaknesses) \\
\hline S1 & $\begin{array}{l}\text { Merupakan Perguruan Tinggi Negeri } \\
\text { Agama Islam satu-satunya di Kabupaten } \\
\text { Rejang Lebong }\end{array}$ & W1 & $\begin{array}{l}\text { Visi dan misi yang ditetapkan STAIN } \\
\text { Curup belum menjadi pedoman dan } \\
\text { arahan dalam menyusun kebijakan }\end{array}$ \\
\hline S2 & $\begin{array}{l}\text { Sebagian besar dosen dan karyawan } \\
\text { STAIN Curup di bawah usia } 45 \text { tahun }\end{array}$ & W2 & $\begin{array}{l}\text { Lemahnya koordinasi dan komunikasi } \\
\text { antar unit organisasi . }\end{array}$ \\
\hline S3 & $\begin{array}{l}\text { Biaya pendidikan terjangkau oleh } \\
\text { masyarakat }\end{array}$ & W3 & $\begin{array}{l}\text { Program studi yang sudah terakreditasi } \\
\text { dari } 10 \text { program studi baru } 3 \text { prodi } \\
\text { (terakreditasi } \mathrm{B} \text { ), sisanya } 7 \text { prodi baru } \\
\text { masih terakreditasi } \mathrm{C}\end{array}$ \\
\hline S4 & $\begin{array}{l}\text { Peran sosial keagamaan civitas akademika } \\
\text { di masyarakat cukup tinggi }\end{array}$ & W4 & $\begin{array}{l}\text { Input (mahasiswa) STAIN Curup belum } \\
\text { memenuhi standar yang ditetapkan }\end{array}$ \\
\hline S5 & $\begin{array}{l}\text { Sebanyak } 75 \text { orang dosen dari } 97 \text { orang } \\
\text { dosen telah tersertifikasi }\end{array}$ & W5 & $\begin{array}{lll}\text { Standar kompetensi } & \text { lulusan } & \text { belum } \\
\text { sesuai harapan } & & \\
\end{array}$ \\
\hline S6 & $\begin{array}{llr}\text { Komitmen } & \text { pimpinan } & \text { terhadap } \\
\text { pengembangan } & \text { STAIN Curup cukup } \\
\text { tinggi } & & \end{array}$ & W6 & $\begin{array}{lll}\text { Kurang } & \text { optimalnya } & \text { pelayanan } \\
\text { pendidikan } & & \\
\end{array}$ \\
\hline S7 & $\begin{array}{l}\text { Tersedia beasiswa bagi mahasiswa } \\
\text { berprestasi atau kurang mampu }\end{array}$ & W7 & $\begin{array}{l}\text { Rasio SDM (dosen dan pegawai) dan } \\
\text { mahasiswa tidak ideal. }\end{array}$ \\
\hline & & W8 & $\begin{array}{l}\text { Terbatasnya dosen yang bergelar doktor } \\
\text { dan baru ada satu orang guru besar }\end{array}$ \\
\hline & & W9 & $\begin{array}{l}\text { Proses pembelajaran belum sesuai } \\
\text { dengan kompetensi lulusan }\end{array}$ \\
\hline & & W10 & Pendanaanmasih tergantung pada DIPA \\
\hline & & W11 & $\begin{array}{l}\text { Pelaksanaan Tri Dharma Perguruan } \\
\text { Tinggi yang belum sinergis }\end{array}$ \\
\hline & & $\overline{\mathrm{W} 12}$ & $\begin{array}{lll}\text { Sarana dan } & \text { prasarana } & \text { kurang } \\
\text { representatif } & & \\
\end{array}$ \\
\hline & & W13 & $\begin{array}{l}\text { Belum digunakannya secara } \text { optimal } \\
\text { fasilitas TI dan akses ke jaringan } \\
\text { internet dan multi media pembelajaran }\end{array}$ \\
\hline & & W14 & $\begin{array}{lrr}\text { Masih banyak } & \text { dosen } & \text { yangbelum } \\
\text { menggunakan } & \text { fasilitas } & \text { dan } \\
\text { keterampilannya untuk } & \text { pembelajaran } \\
\text { yang berbasis multimedia } & & \\
\end{array}$ \\
\hline & & W15 & $\begin{array}{l}\text { Manfaat kajian riset dan pengabdian } \\
\text { belum mampu mengatasi problem sosial } \\
\text { dan pengembangan keilmuan }\end{array}$ \\
\hline & & W16 & $\begin{array}{l}\text { Lemahnya memanfaatkan peluang- } \\
\text { peluan kerjasama dengan pihak ketiga }\end{array}$ \\
\hline & & W17 & $\begin{array}{l}\text { Atmosfir Akademik dan Non Akademik } \\
\text { STAIN Curup kurang sehat }\end{array}$ \\
\hline & R EKSTERNAL & & \\
\hline No. & Peluang (Opportunities) & No. & Ancaman (Threaths) \\
\hline $\mathrm{O} 1$ & $\begin{array}{l}\text { Kebijakan otonomi daerah memberi } \\
\text { peluang bagi STAIN Curup untuk } \\
\text { berpartisipasi dan terlibat dalam program- } \\
\text { program pembangunan daerah }\end{array}$ & T1 & $\begin{array}{l}\text { Praktik keberagaman masyarakat } \\
\text { cenderung semakin normatif dan } \\
\text { mementingkan aspek formalitas, ritual } \\
\text { dan simbolik }\end{array}$ \\
\hline $\mathrm{O} 2$ & Anggaran untuk pendidikan sebanyak & T2 & Kecenderungan masyarakat social yang \\
\hline
\end{tabular}




\begin{tabular}{|c|c|c|c|}
\hline & $20 \%$. & & $\begin{array}{l}\text { semakin konsumtif, hedonistic, } \\
\text { materialistic, dan serakah berdampak } \\
\text { pada maraknya praktik-praktik } \\
\text { eksploitatif, korupsi dan } \\
\text { penyalahgunaan wewenang }\end{array}$ \\
\hline O3 & $\begin{array}{l}\text { Kualifikasi guru harus memiliki ijazah } \\
\text { S1(strata 1) }\end{array}$ & T3 & $\begin{array}{l}\text { Kerusakan ekosistem meyebabkan } \\
\text { rusaknya tata ruang STAIN Curup }\end{array}$ \\
\hline O4 & $\begin{array}{lll}\text { Perluasan } & \text { Kewenangan } & \text { Pengadilan } \\
\text { Agama (PA) } & & \end{array}$ & $\mathrm{T} 4$ & $\begin{array}{l}\text { Globalisasi yang didukung oleh ideology } \\
\text { kapitalisme dan neoliberalisme } \\
\text { berdampakpada logika pasar sebagai } \\
\text { panglima dunia (hegemoni). }\end{array}$ \\
\hline O5 & $\begin{array}{l}\text { Komitmen Pemerintah Daerah Rejang } \\
\text { Lebong untuk membangun masyarakat } \\
\text { religius memberi peluang bagi STAIN } \\
\text { Curup untuk berpartisipasi secara aktif } \\
\text { dalam mengisi dan mensukseskan } \\
\text { program-program } \\
\text { pemerintah daerah }\end{array}$ & & \\
\hline O6 & $\begin{array}{l}\text { Terbatasnya sumber daya manusia di } \\
\text { daerah Kabupaten Rejang Lebong dan } \\
\text { sekitarnya menjadi peluang bagi STAIN } \\
\text { Curup untuk menyiapkan tenaga-tenaga } \\
\text { ahli dan trampil di bidang } \\
\text { agama,pendidikan, ekonomi, hokum, dan } \\
\text { social kemasyarakatan }\end{array}$ & & \\
\hline O7 & $\begin{array}{l}\text { Karakter masyarakat Curup yang egaliter } \\
\text { dan heterogen merupakan modal social } \\
\text { bagi STAIN Curup dalam membangun } \\
\text { kampus yang lebih mandiri }\end{array}$ & & \\
\hline O8 & $\begin{array}{l}\text { Perkembangan pengetahuan dan } \\
\text { teknologi informasi berimplikasi pada } \\
\text { perubahan nilai-nilai yang diyakini } \\
\text { masyarakat }\end{array}$ & & \\
\hline O9 & $\begin{array}{l}\text { Munculnya kecenderungan lembaga- } \\
\text { lembaga donor mancanegara yang mulai } \\
\text { melirik kerjasama dengan lembaga di } \\
\text { Indonesia }\end{array}$ & & \\
\hline
\end{tabular}

\section{Perumusan Visi dan Misi STAIN Curup}

\section{a. Visi}

Menjadi lembaga pendidikan tinggi Islam yang bermutu, religius, inovatif dan kompetitif di wilayah Sumatera pada tahun 2024. Hal yang perlu untuk diperhatikan pada visi tersebut adalah adanya tenggang waktu. Dengan waktu yang terbatas, diperlukan kuantitas sumber daya yang cukup besar serta strategi pengalokasian sumber daya agar visi tersebut dapat tercapai. Selanjutnya hal yang perlu dipikirkan adalah what next? Jika batas waktu visi berakhir, tindakan apa yang akan dilakukan.

\section{b. Misi}

1. Menyelenggarakan pendidikan dan pengajaran yang bermutu, religius, dan menghasilkan ilmu pengetahuan yang inovatif dan kompetitif . 
2. Menyelenggarakan dan mengembangkan berbagai bidang disiplin ilmu melalui penelitian kompetitif yang bermutu dan handal.

3. Melaksanakan kegiatan pengabdian kepada masyarakat sebagai proses pemantapan dan pemanfaatan pengembangan ilmu pengetahuan.

4. Mengintegrasikan nilai-nilai Islam dalam pengembangan ilmu pengetahuan dan teknologi menuju lembaga yang bermutu, religius, inovatif dan kompetitif.

5. Membangun tatakelola yang professional,transparan dan akuntabel untuk menghasilkan pelayanan prima bagi civitas akademika dan masyarakat.

6. Membangun kerjasama yang luas dengan berbagai pihak, instansi pemerintah dan swasta, di dalam dan luar negeri, sehingga mampu mendukung pelaksanaan tri dharma pendidikan tinggi yang bermutu.

7. Melaksanakan kegiatan mahasiswa yang berbasis pengembangan soft skill dan berkarakter.

Misi yang diemban di atas sesuai dengan tupoksi STAIN Curup sebagai pengelola pendidikan, pelatihan serta penyuluhan SDM bidang pendidikan dengan demikian menjelaskan mengapa organisasi ini ada. Adapun strategi yang dilakukan dalam menanamkam visi dan misi tersebut adalah dengan mencantumkan visi dan misi tersebut dalam paparan arah pengembangan SDM STAIN Curup. Disamping itu juga dengan memasang $x$-banner di sudut-sudut kantor.

\section{Analisis Desain Organisasi Sebagai Modal Awal Perencanaan Strategis \\ 1. Konsep Desain Organisasi Sebagai Modal Awal Perencanaan Strategis}

Dalam fungsi pengorganisasian, manajer mengalokasikan keseluruhan sumber daya organisasi sesuai dengan rencana yang telah dibuat berdasarkan suatu kerangka kerja organisasi tertentu. Kerangka kerja tersebut dinamakan sebagai Desain Organisasi.

Menurut Henry Mintzberg dalam menciptakan suatu desain organisasi yang efektif, maka mengemukan pendapatnya yang ditulis dalam sebuah buku Structure In Five : Designing Efective Organization. Buku ini menjelaskan bagaimana organisasi dibentuk dari beberapa elemen untuk menjadi suatu konfigurasi/struktur yang lebih efektif. Terdapat dua argumentasi sebagai dasar simpulan yang menyatakan konfigurasi mendorong keefektifan organisasi yaitu :

a. seleksi alamiah, dalam hal ini lingkungan mendorong bentuk organisasi untuk melanjutkan kelangsungan hidupnya, agar terjadi efisien biaya dan dapat bersaing, sebuah organisasi harus dapat menyesuaikan diri dengan sifat struktural industrinya.

b. organisasi dapat didorong ke arah konfigurasi tertentu untuk mencapai konsistensi dalam karakteristik internal organisasi sehingga cocok dengan situasi mereka. 


\section{Struktur Organisasi STAIN Curup}

Struktur organisasi STAIN Curup dalam Peraturan Menteri Agama No. 30 Tahun 2013 tentang Organisasi dan Tata Kerja Sekolah Tinggi Agama Islam Negeri Curup disajikan pada gambar 3.1. berikut :

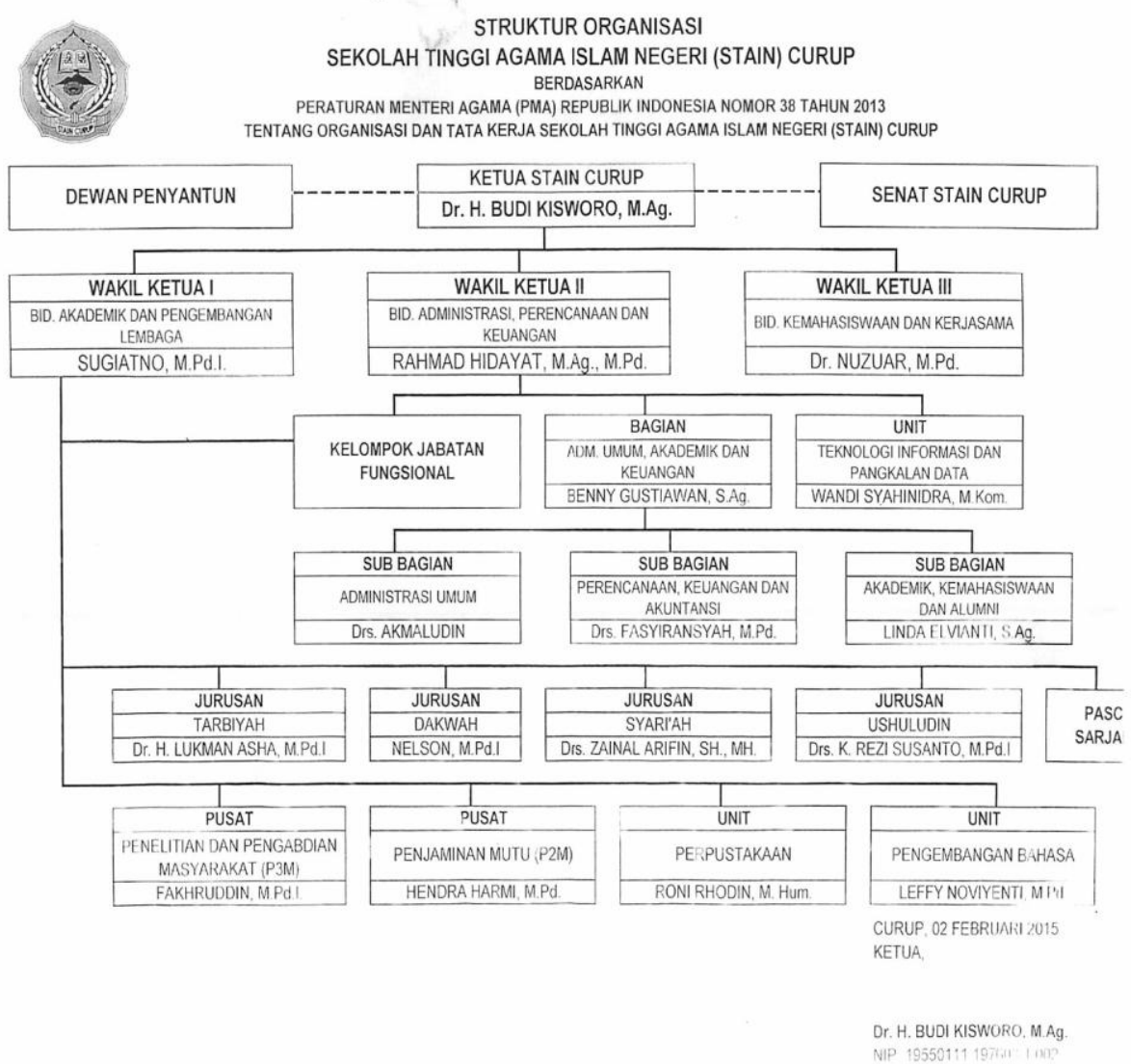

\section{Gambar 3.1. Struktur Organisasi STAIN Curup}

Bila ditelusuri dari latar belakang bidang pendidikan, penempatan SDM di dalam unit kerja organisasi sudah menempatkan orang yang tepat di posisi yang tepat. Dominasi pegawai di STAIN Curup adalah lulusan dari perguruan tinggi agama Islam. Sehingga kompetensi di bidang perencanaan, keuangan, kepegawaian, tata usaha, analisis, evaluasi, pendidikan serta pelatihan sudah dimiliki sebagian besar pegawainya. Job description para pegawai terkecuali untuk pejabat struktural dan jabatan fungsional tertentu belum ada. Pegawai bekerja hanya berdasarkan apa yang diperintahkan oleh atasan dan belajar dengan melakukan (learning by doing). Seringkali juga terjadi ketimpangan beban pekerjaan antara satu orang dengan yang lain. 
Dengan intensitas pekerjaan yang besar dan padat dengan keterbatasan kuantitas dan kualitas pegawainya, seringkali terjadi lintas sub bidang dalam pelaksanaan pekerjaan dan pendelegasian langsung dari atasan tanpa melalui atasan langsung. Di samping itu juga pembentukan kelompok kerja dalam suatu tim sehingga terdapat proses pembelajaran di dalamnya. Pembentukan kelompok kerja ini terkadang menjadi dilema karena sering terjadi lintas bidang pekerjaan. Sehingga struktur organisasi lebih mirip dengan struktur organisasi matriks.

Agar pegawai di STAIN Curup dapat bekerja dengan efektif, maka dilakukanlah pelatihan-pelatihan, pendidikan lanjutan, serta penyusunan job description. Berdasarkan Peraturan Menteri Agama (PMA) Republik Indonesia nomor: 38 Tahun 2013 tentang Organisasi dan Tata Kerja Sekolah Tinggi Agama Islam Negeri (STAIN) Curup menyelenggarakan pendidikan dan pengajaran yang bertujuan:

a. Menghasilkan pendidikan dan pengajaran yang bermutu, religious, kompetitif dan inovatif

b. Menghasilkan berbagai ilmu pengetahuan melalui penelitian kompettitif yang bermutu dan handal;

c. Menghasilkan kegiatan pengabdian masyarakat yang bermutu, inovatif dan kompetitif sebagai proses pemantapan dan pemanfaatan dan pengembangan ilmu pengetahuan ;

d. Menghasilkan integrasi nilai-nilai Islam dalam pengembangan ilmu pengetahuan dan teknologi menuju lembaga yang bermutu, religious, kompetetif, dan inovatif

e. Menghasilkan tata kelola yang professional; transparent dan akuntabel bagi civitas akademika dan masyarakat;

f. Menghasilkan kerjasama yang luas dengan berbagai pihak, instansi pemerintah dan swasta di dalam dan luar negeri, sehingga mampu mendukung pelaksanaan tri dharma perguruan tinggi yang bermutu.

g. Menghasilkan kegiatan mahasiswa yang berbasis pengembangan soft skill dan berkarakter;

Dengan demikian dapat dikatakan bahwa desain organisasi STAIN Curup adalah strategy follow function karena kemampuan organisasi merupakan produk dari struktur organisasi.

\section{SDM di STAIN Curup}

Dengan banyaknya program dan kegiatan serta jumlah SDM yang ada tidak mampu menanggung beban pekerjaan yang banyak mengingat waktu kerja yang terbatas, STAIN Curup membutuhkan tambahan dosen dan pegawai. Walaupun terjadi moratorium PNS sejak tahun 2012, STAIN Curup dapat menambah pegawai kira-kira 90\%. Hal ini dilakukan dengan membuka kesempatan. Di samping itu juga bantuan dari tenaga magang sangat berpengaruh- tenaga 
pengajar pada pelaksanaan Renstra. Gambar 4 menyajikan jumlah SDM STAIN Curup tahun 2010-2014.

\section{a.Dosen'Tetap}

Tabel 4.1

Jumlah Dosen Tetap Tahun 2014

\begin{tabular}{|l|l|l|}
\hline No & Golongan & Jumlah \\
\hline 1. & III/a & $\mathbf{2}$ \\
\hline 2. & III/b & 21 \\
\hline 3. & III/c & 19 \\
\hline 4. & III/d & 22 \\
\hline 5. & IV $/$ a & 19 \\
\hline 6. & IV $/$ b & 6 \\
\hline 7. & IV/c & 4 \\
\hline 8. & IV/d & 0 \\
\hline 9. & IV/e & $\mathbf{0}$ \\
\hline
\end{tabular}

b.Dosen Tidak Tetap

Tabel 4.2

Jumlah Dosen Tidak Tetap Tahun 2014

\begin{tabular}{|l|l|l|}
\hline No & Jabatan Fungsional & Jumlah \\
\hline 1. & Asisten Ahli & 93 \\
\hline 2. & Lektor & $\mathbf{8}$ \\
\hline 3. & Lektor Kepala & 15 \\
\hline 4. & Guru Besar & - \\
\hline Jumlah & 116 \\
\hline
\end{tabular}

Tabel 4.3

Jumlah Mahasiswa STAIN Curup (2010-2014)

\begin{tabular}{|l|l|l|}
\hline No & Tahun & Jumlah \\
\hline 1 & 2010 & $\mathbf{2 6 7 3}$ \\
\hline 2 & 2011 & $\mathbf{3 6 2 3}$ \\
\hline 3 & 2012 & $\mathbf{4 1 9 4}$ \\
\hline 4 & 2013 & $\mathbf{5 1 0 6}$ \\
\hline 5 & 2014 & $\mathbf{5 3 7 6}$ \\
\hline
\end{tabular}

Calon mahasiswa STAIN Curup tidak hanya terbatas pada lulusan madrasah (MA/MAN) dan pesantren, melainkan juga lulusan Sekolah Menengah Atas (SMA) dan kejuruan (SMK). Ditemukan kenyataan, bahwa calon mahasiswa tersebut banyak yang tidak menguasai ilmu-ilmu keislaman dasar, seperti baca dan tulis Al-Qur'an, fiqih, aqidah, akhlak, dan sejenisnya.Demikian pula, pengetahuan bahasa Arab mereka sangat minim. Akibatnya, mereka tidak bisa menyesuaikan diri dalam proses pembelajaran di STAIN Curup. Beberapa program memang sudah disiapkan untuk meningkatkan kemampuan membaca al-qur'an dan bahasa, antara lain praktikum Bahasa Arab dan Baca Tulis al-Qur'an. Namun, program matrikulasi tersebut ternyata juga belum bisa mendongkrak pengetahuan mereka, sebab sampai mereka menjelang lulus atau bahkan sudah diwisuda pun mereka belum menguasai bahasa Arab dan Baca'Tulis al-Qur'an dengan mahir. 
Standar kompetensi lulusan belum sesuai harapan.Jumlah lulusan mahasiswa STAIN Curup sejak tahun 2010 sampai dengan Agustus 2014 adalah sebanyak 4336 lulusan dengan rincian sebagai berikut:

Tabel 4.4

Jumlah alumni STAIN Curup (2010-2014)

\begin{tabular}{|l|l|l|}
\hline No & Tahun & Jumlah \\
\hline 1 & 2010 & $\mathbf{3 6 5}$ \\
\hline 2 & 2011 & $\mathbf{6 4 6}$ \\
\hline 3 & 2012 & $\mathbf{7 2 5}$ \\
\hline 4 & 2013 & 415 \\
\hline 5 & 2014 & $\mathbf{7 1 5}$ \\
\hline
\end{tabular}

Pada tingkat lokal, utamanya Kabupaten Rejang Lebong, memang terdapat persepsi yang baik dari masyarakat terhadap kompetensi lulusan STAIN Curup. Hal itu, misalnya, sebagaimana ditunjukkan oleh hasil kajian yang dilakukan Umum B Karyanto (2010), bahwa persepsi masyarakat pengguna se-Kabupaten Rejang Lebong baik sekolah/madrasah negeri maupun swasta terhadap kompetensi pedagogik, kepribadian, sosial dan profesional alumni JurusanTarbiyah STAIN Curup adalah baik. Namun demikian, di tingkat provinsi atau nasional, tidak banyak alumni STAIN Curup yang telah menunjukkan kiprahnya secara baik.Ini tentu karena kompetensi pedagogik, kepribadian, sosial dan profesional alumni STAIN Curup kalah dengan alumni perguruan tinggi lainnya.

Adapun jumlah pegawai STAIN Curup sebanyak 93 orang, baik tetap maupun tidak tetap, dengan rincian sebagai berikut:

Tabel 4.5

Jumlah Pegawai Tetap Tahun 2014

\begin{tabular}{|c|c|c|c|c|c|c|c|c|c|c|c|c|c|c|}
\hline \multirow{3}{*}{ No } & \multirow{3}{*}{ Golongan } & \multicolumn{12}{|c|}{ TINGKAT PENDIDIKAN } & \multirow{3}{*}{ Jumlah } \\
\hline & & \multicolumn{2}{|c|}{ SD } & \multicolumn{2}{|c|}{ SMP } & \multicolumn{2}{|c|}{ SMA } & \multicolumn{2}{|c|}{ S1 } & \multicolumn{2}{|l|}{ S2 } & \multicolumn{2}{|l|}{ S3 } & \\
\hline & & $\mathrm{L}$ & $\mathrm{P}$ & $\mathrm{L}$ & $\mathrm{P}$ & $\mathrm{L}$ & $\mathrm{P}$ & $\mathrm{L}$ & $\mathrm{P}$ & $\mathrm{L}$ & $\mathrm{P}$ & $\mathrm{L}$ & $\mathrm{P}$ & \\
\hline 1. & $\mathrm{II} / \mathrm{a}$ & - & - & - & - & - & - & - & - & - & - & - & - & 0 \\
\hline 2. & $\mathrm{II} / \mathrm{b}$ & - & - & - & - & 1 & - & - & - & - & - & - & - & 1 \\
\hline 3. & $\mathrm{II} / \mathrm{c}$ & - & - & - & - & - & - & 1 & - & - & - & - & - & 1 \\
\hline 4. & $\mathrm{II} / \mathrm{d}$ & - & - & - & - & - & - & - & - & - & - & - & - & 0 \\
\hline 5. & $\mathrm{III} / \mathrm{a}$ & - & - & - & - & - & - & 5 & 3 & 1 & - & - & - & 9 \\
\hline 6. & $\mathrm{III} / \mathrm{b}$ & - & - & - & - & - & - & 8 & 7 & 5 & - & - & - & 20 \\
\hline 7. & III/c & - & - & - & - & - & - & 2 & - & 2 & - & - & - & 4 \\
\hline 8. & $\mathrm{III} / \mathrm{d}$ & - & - & - & - & - & - & 3 & 1 & 3 & - & - & - & 7 \\
\hline 9. & $\mathrm{IV} / \mathrm{a}$ & - & - & - & - & - & - & - & - & 1 & - & - & - & 1 \\
\hline
\end{tabular}

Jika dibuat rerata perbandingan antara dosen (sebanyak 93) dan mahasiswa (sebanyak 5376), maka ditemukan angka 1: 30. Namun demikian, jika dilihat lebih jauh, rasio perbandingan tersebut belum ideal. Terbatasnya dosen yang bergelar doktor, dan baru hanya ada satu orang guru besar. Sejak berdiri sampai sekarang, STAIN Curup baru memiliki 8 (delapan) orang dosen bergelar doktor, dengan rincian sebagai berikut:

Tabel 4.6

Jumlah Doktor Tahun 2014 


\begin{tabular}{|l|l|l|}
\hline No & Jurusan & Jumlah Doktor \\
\hline 1. & Tarbiyah & 7 orang \\
\hline 2. & Dakwah & - \\
\hline 3. & Syariah & 1 orang \\
\hline Jumlah & 8 orang \\
\hline
\end{tabular}

Sejak berdiri sampai sekarang STAIN Curup baru memiliki seorang dosen yang bergelar guru besar.

\section{Analisis Pembiayaan Dan Sistem Penyangga Organisasi}

\section{Konsep Pembiayaan dan Sistem Penyangga Organisasi}

Anggaran sangat penting untuk implementasi strategi yang berhasil karena:

a. Setiap unit organisasi harus memiliki sumber daya yang dibutuhkan untuk melakukan bagiannya dalam rencana strategis;

b. Mereka melindungi kondisi keuangan perusahaan dan menghilangkan pemborosan uang tunai;

c. Terlalu sedikit dana menghilangkan sub-unit dari kapasitas untuk melaksanakan bagian mereka dari rencana strategis;

d. Terlalu banyak sumber daya pendanaan limbah organisasi dan mengurangi kinerja keuangan;

e. Perubahan strategi sering membutuhkan sumber daya bergeser dari satu ke yang lain.

Strategi baru sering memerlukan anggaran realokasi karena:

a. Lebih banyak uang akan dibutuhkan untuk membuat sistem informasi untuk mendukung strategi baru.

b. nsentif kompensasi yang menyertainya cenderung membutuhkan berbagai tingkat pendanaan dari sebelumnya.

c. Kegiatan rantai nilai dan unit organisasi pusat strategi lama belum tentu pusat-tahap dalam strategi baru.

d. Tugas memberdayakan karyawan biasanya mahal.

Tindakan kuat untuk mengalokasikan dana operasional dan memindahkan orang ke unit yang berbeda :

a. Sinyal komitmen yang kuat untuk melaksanakan perubahan strategis dan membantu memberikan kredibilitas terhadap proses implementasi.

b. Bisa disfungsional dalam mencoba menerapkan strategi baru karena kecemasan dan rasa tidak aman.

c. Cenderung menghambat tugas pemberdayaan karyawan dan beralih ke budaya baru.

d. Jarang diperlukan dalam menerapkan strategi baru kecuali strategi baru memerlukan satu strategis yang berbeda kegiatan rantai nilai.

\section{Penyusunan Anggaran}

Strategi yang telah dirumuskan tentu saja berdampak pada postur anggaran

STAIN Curup terus meningkat setiap tahunnya sehingga dapat dianalisis bahwa 
STAIN Curup namun masih banyak memiliki masalah pada pendanaan, masalahnya adalah :

a. Belum adanya kejelasan dan kelengkapan dokumen kebijakan pengelolaan dana

b. Belum adanya sumber biaya yang diperoleh dari hibah, business unit (unit bisnis/ usaha/ ventura), hasil kerjasama akademik, alumni, masyarakat dan sebagainya per tahun.

c. Sudah ada pedoman pertanggungjawaban penggunaan dana sesuai dengan peraturan yang berlaku

d. Mekanisme penetapan biaya pendidikan mahasiswa.

e. Persentase dana PT yang berasal dari mahasiswa untuk mendukung keseluruhan pembiayaan pendidikan.

f. Sudah ada kejelasan kebijakan dan mekanisme pembiayaan mahasiswa.

g. Belum konsistennya penggunaan dana operasional pendidikan, penelitian, pengabdian pada masyarakat.

h. Belum adanya kejelasan sistem monitoring dan evaluasi pendanaan internal.

i. Belum adanya laporan keuangan yang transparan dan dapat diakses oleh semua pemangku kepentingan.

Pendanaan masih bergantung pada DIPA STAIN Curup. Sumber pendanaan STAIN Curup masih bergantung pada dana dari pemerintah (bersumber dari pajak dan non pajak termasuk SPP), berupa dana DIPA. Adapun jumlah dana DIPA yang diterima STAIN Curup dari tahun 2010 hingga tahun 2014 sebagai berikut:

Tabel 5.1

Jumlah dana DIPA 2010-2014

\begin{tabular}{|l|l|l|}
\hline No & Tahun Anggaran & Jumlah \\
\hline 1. & 2010 & Rp. 20.377 .295 .677 \\
\hline 2. & 2011 & Rp. 23.206 .429 .795 \\
\hline 3. & 2012 & Rp. 24.839 .455 .800 \\
\hline 4. & 2013 & Rp. 38.607 .762 .994 \\
\hline 5. & 2014 & Rp. 45.877 .896 .000 \\
\hline
\end{tabular}

STAIN Curup baru 1 kali menerima bantuan dari pemerintahan daerah Kabupaten Rejang Lebong yakni pada tahun 2012.

\section{Analisis Membangun Kultur Organisasi, Pemimpin Strategis Dan Perannya}

1. Konsep Membangun Kultur Organisasi, Pemimpin Strategis dan Perannya

Budaya merupakan perilaku kolektif atau beberapa orang yang teraktualisasikan dalam kesadaran perilaku tiap individu. Artinya, apabila sebuah perilaku kolektif dijalankan tidak dengan kesadaran (paksaan misalnya), maka hal itu masih belum dapat dikatakan sebagai sebuah budaya.

Dengan pijakan yang sama pula, yaitu perilaku organisasi, maka dapat disimpulkan bahwa dalam sebuah organisasi bisa jadi akan ada beberapa nilai 
budaya yang berbeda dikarenakan dalam sebuah organisasi tidak tertutup kemungkinan adanya variasi perilaku organisasi yang dimiliki oleh setiap anggota organisasi. Masing-masing punya karakteristik yang berbeda, sehingga perilaku organisasinya pun akan berbeda. Dari perbedaan (variasi) perilaku organisasi ini, maka nantinya akan dapat membentuk budaya organisasi yang beraneka ragam pula. Nantinya, budaya-budaya tersebut ada yang bersifat mayoritas (Dominant Culture) dan ada pula yang bersifat minoritas (Sub-Culture). Secara lebih jelas, dapat dilihat pada gambar berikut.

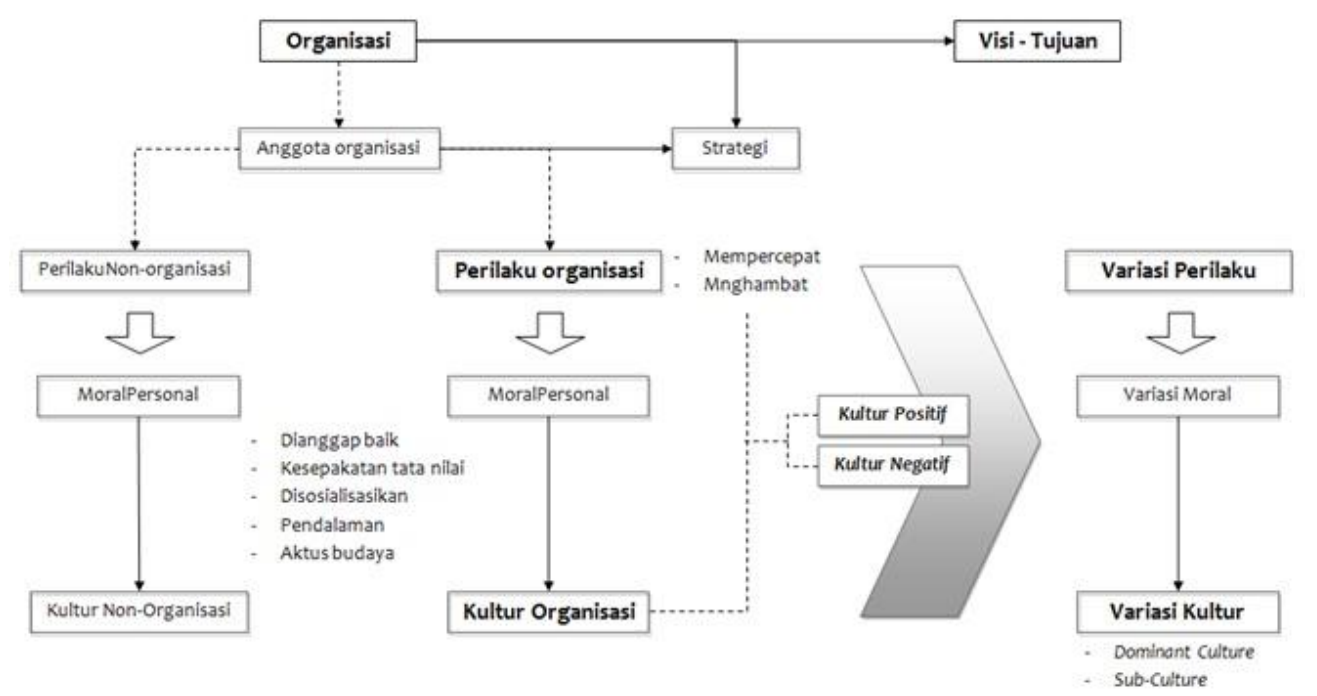

\section{Gambar 6.1. Proses Terbentuknya Keanekaragaman Budaya Organisasi}

Konsep kepemimpinan telah berpuluh-puluh tahun diteliti oleh ratusan ahli, melalui berbagai metode, berfokus pada berbagai elemen kepemimpinan, dengan berbagai sudut pandang. Tentunya hasil yang diperoleh juga beragam. Salah satu temuan yang paling konsisten di antara ratusan penelitian tersebut adalah bahwa satu gaya/tipe kepemimpinan tidak dapat diterapkan secara terusmenerus, melainkan bergantung pada: situasi, tugas yang diemban, dan karakteristik dari para bawahan yang dipimpinnya. Salah satu contoh situasi yang berbeda-beda di mana seorang pemimpin menjalankan perannya, adalah fase/tahap-tahap sebuah organisasi dalam siklusnya. Peran seorang pemimpin pada saat organisasi baru dibentuk dan pada saat organisasi sudah mulai "menua", sangatlah berbeda.

\section{Kepemimpinan dalam Membentuk Budaya Organisasi di STAIN Curup}

Kepemimpinan di STAIN Curup juga mengambil peranan yang penting. Dalam mencapai tujuannya pemimpin selalu menanamkan budaya kerja yang disiplin, bersih, rapi,cepat dan prima. Pemimpin juga memiliki visi yang jauh ke 
depan sehingga terkadang agak sulit bagi dosen dan karyawan untuk memahaminya. Pemimpin di STAIN Curup mendorong ide-ide atau gagasan dari bawah (bottom up) dan setiap orang diberikan kesempatan untuk menggali potensi dan minat untuk mengembangkan diri pada spesialisasinya di bidangbidang tertentu.

Berikut empat fase peran pemimpin dalam membentuk budaya organisasi, yaitu:

a. Fase Pendirian: Pemimpin sebagai Penggerak Organisasi

Pada masa-masa awal pergantian Ketua STAIN Curup yang baru yaitu tahun 2012 awal, Ketua STAIN Curup memberikan visi;arah dan tujuan kemana organisasi menuju. Ketua juga memberi energi bagi seluruh dosen dan karyawan dengan selalu memberi motivasi kerja bagi dosen dan karyawan khususnya yang baru-baru dan masih muda.

b. Fase Pembentukan: Pemimpin sebagai Pencipta Budaya

Ketua menerapkan nilai-nilai dalam melakukan pekerjaan yang disiplin, cepat, loyal, bersih dan rapi dengan tiga cara, yaitu:

i. Ia hanya merekrut orang-orang yang mau bekerja ekstra;

ii. Ia mengkomunikasikan, mensosialisasikan, serta melakukan indoktrinasi kepada para bawahannya tentang nilai-nilai dan cara berpikir dan bertingkah laku yang ia inginkan;

iii. Ia memberikan contoh kepada para bawahannya bagaimana seharusnya berpikir dan bertingkah laku, seperti datang kerja paling awal, memakai baju dengan rapi.

c. Fase Pemeliharaan: Pemimpin sebagai Pemelihara Budaya

Senantiasa melakukan perbaikan dan mencari cara dalam pengembangan organisasi. Selain itu juga melakukan kaderisasi kepada pegawai yang dianggap mampu untuk memegang suatu kegiatan sebagai Kepala Unit.

d. Fase Perubahan: Pemimpin sebagai Agen Perubahan

Kegagalan pada usaha yang dilakukan cepat ditanggapi dengan membentuk tim baru untuk menangani masalah yang ada. Perubahan lingkungan yang senantiasa terjadi seperti adanya kebijakan baru dan sebagainya disikapi dengan cepat agar dapat melayani pelanggan dengan informasi yang up to date.

\section{Analisis Menyelaraskan Proses Internal Dan Proses Belajar Dalam Organisasi}

\section{Konsep Menyelaraskan Proses Internal dan Proses Belajar Dalam Organisasi}

Semakin besar suatu organisasi, maka semakin perlu organisasi tersebut melakukan penyelarasan agar tidak terjadi kegagalan pengertian di antara bagianbagian yang satu sama lain saling terkait. Keuntungan besar perusahaan tidak terjadi hanya dari usaha organisasi itu sendiri, namun bisa juga berkat pengaruh dari lingkungan eksternal. 
Balanced Scorecard menempatkan perspektif stakeholder sebagai perspektif tertinggi. Fokus kepada pelanggan dan menyediakan pelayanan berkualitas tinggi ditekankan secara khusus. Perspektif lainnya adalah untuk mendukung fokus strategis dari perspektif stakeholder, yang pada kenyataannya adalah manusia sebagai individu maupun sebagai anggota kelompok masyarakat. Dengan kata lain, balancedscorecard dikembangkan dengan basis manusia sebagai inti, dalam hal ini inti dari pembangunan STAIN Curup.

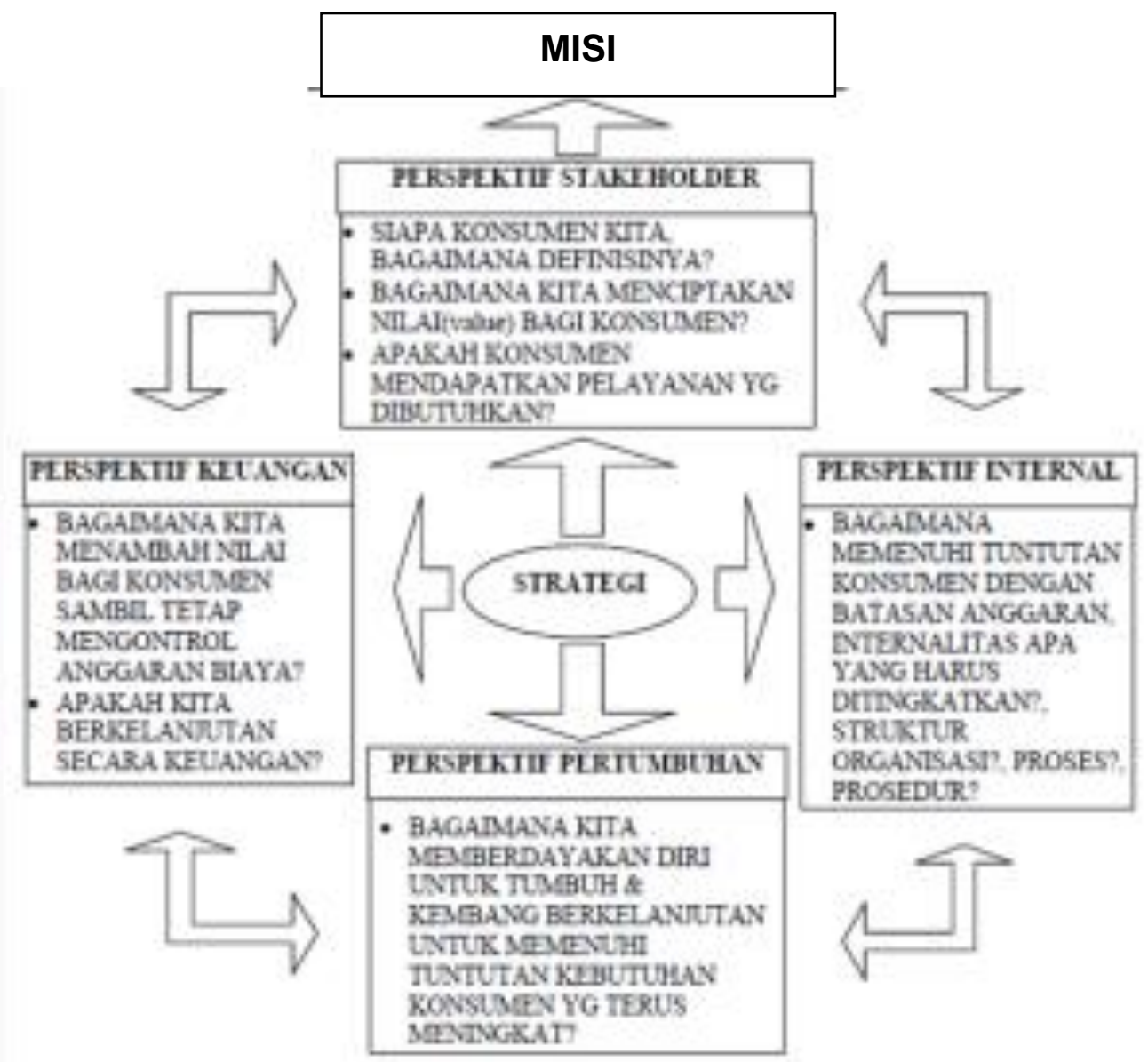

Gambar 7.1. Diagram Perspektif Orientasi dan Misi

Setiap upaya pembangunan menuntut perencanaan terlebih dahulu. Balanced Scorecard mensintesiskan 4 (empat) perspektif yaitu:

1. Perspektif Stakeholders;

2. Perspektif Keuangan;

3. Perspektif Pertumbuhan;

4. Perspektif Internal. 
Berbeda dengan perencanaan ekstrapolatif yang terfokus pada antisipasi/reaktif terhadap ekstrapolasi statistik ke masa depan, perencanaan visioner bersifat proaktif dengan adanya kisi-kisi dari keempat perspektif tersebut, yang mampu mengakomodasikan dinamika masa depan. Manfaat khusus dari pendekatan ini adalah cakupannya yang sekaligus berfungsi sebagai perangkat pengelolaan (management tool) dan perangkat pengukuran keberhasilan (measurement too), yang melengkapinya sebagai perangkat perencanaan (planning tool), dengan uraian sebagai berikut:

Sebagai perangkat pengelolaan, manfaatnya adalah:

1. Memperjelas dan membantu terbentuknya konsensus bagi perumusan strategi (khususnya di antara para penanggungjawab pelaksanaannya).

2. Menyelaraskan tujuan-tujuan strategis (strategic goals) melalui pengembangan saling keterkaitan yang jelas.

3. Memungkinkan komunikasi tentang strategi secara menyeluruh di dalam organisasi pemerintah daerah.

4. Mensyaratkan penjabaran sistematik dari strategi secara bertingkat di dalam organisasi pemerintah daerah.

5. Mengidentifikasi inisiatif strategis dalam hubungannya dengan setiap organ pemerintah daerah.

6. Mensyaratkan kajian secara berkala.

Sebagai perangkat pengukuran keberhasilan, manfaatnya adalah:

1. Mensyaratkan pengembangan ukuran-ukuran keberhasilan di dalam setiap perspektif.

2. Memastikan bahwa pengelolaan kinerja jelas terkait dengan pernyataan strategi dan memberikan kunci-kunci kinerja di mana organ pemerintah daerah tersebut diharapkan tampil dengan memuaskan.

3. Menawarkan metoda grafis untuk melihat hubungan antara setiap variabel.

4. Menciptakan kerangka yang nyata untuk menyusun laporan pertanggungjawaban pelaksanaan rencana terhadap capaian keberhasilan.

\section{a. Balanced Score Card di STAIN Curup}

Dalam dokumentasi data ditemukan adanya balanced scorecard yang dalam pengerjaannya diinisiasi oleh STAIN Curup dan disajikan dalam gambar 7.2. Hal ini juga terkait dengan adanya reformasi birokrasi PNS di lingkungan Kementerian Agama. Sebagai tindak lanjut hasil balanced score card tersebut, Meskipun demikian, balanced scorecard belum diterapkan secara menyeluruh dalam perencanaan strategis, manajemen strategis, strategi implementasi dan evaluasi. 


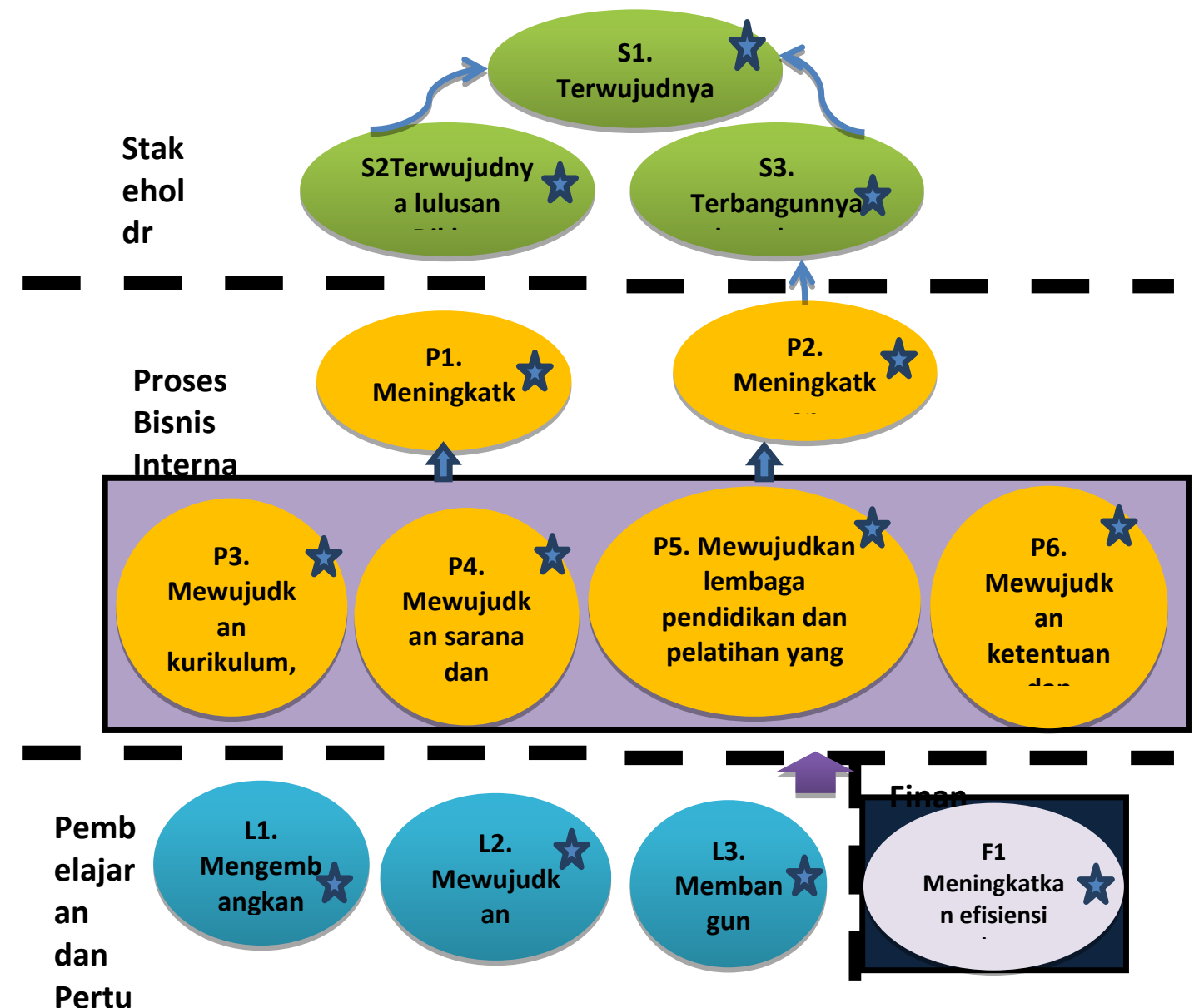

Gambar 7.2. Peta Strategi Balanced Scorecard STAIN Curup

Analisis Sentralisasi Dan Desentralisasi Dalam Manajemen Strategis

1. Konsep Sentralisasi dan Desentralisasi dalam Manajemen Strategis

Perencanaan strategis lebih menonjolkan nilai-nilai dan manajemen strategis yang lebih berpegang pada fakta memerlukan proses pengambilan keputusan dengan mempertimbangkan alokasi sumber daya.

Didalam struktur organisasi yang berbentuk organisasi lini (line organization), garis perintah atau kekuasaan dan tanggung jawab membentang tegak lurus dari atas kebawah atau dari pimpinan atasan atau pimpinan atasan atau pusat sampai kepada orang yang paling bawah.

Desentralisasi adalah adanya pembagian kewenangan oleh tingkat-tingkat organisasi, kepada organisasi dibawahnya. Implikasi dari hal tersebut adalah 
desentralisasi akan membuat tanggung jawab yang lebih besar kepada pimpinan dalam melaksanakan tugas serta memberikan kebebasan untuk bertindak.dengan desentralisasi akan meningkatkan independensi para administrator untuk berpikir dan bertindak dalam satu tim tanpa mengorbankan kebutuhan organisasi.

\section{a. Kedudukan STAIN Curup}

Seiring dengan perkembangan zaman, maka banyak perubahan kebijakan atau lahirnya kebijakan-kebijakan baru di pusat pemerintahan yang berimbas ke daerah-daerah.Salah satu perubahan tersebut adalah dalam dunia pendidikan, khususnya lembaga-lembaga pendidikan tinggi agama yang diselenggarakan oleh Departemen Agama. Dengan lahirnya peraturan baru IAIN cabang yang diharuskan menjadi sekolah tinggi dengan nama Sekolah Tinggi Agama Islam Negeri (STAIN). Fakultas Ushuluddin IAIN Raden Fatah Curup sebagai cabang dari IAIN Raden Fatah Palembang berubah status dari IAIN menjadi STAIN Curup. Secara yuridis formal, perubahan tersebut dituangkan dalam Keputusan Presiden No. 11 Tahun 1997.

Hingga saat ini STAIN Curup telah memiliki tiga Jurusan:

1) Jurusan Tarbiyah

Jurusan Tarbiyah menyengggarakan lima Program Studi yaitu

i. Program Studi Pendidikan Agama Islam

ii. Program Studi Tadris Bahasa Inggris

iii. Program Studi Tadris Bahasa Arab

iv. Program Studi Pendidikan Guru Madrasah Ibtidayah

v. Program Studi Manajemen Pendidikan Islam

2) Jurusan Syari'ah

Jurusan Syari'ah terdiri dari 2 program studi yakni :

i. Ahwal Syakhshiyah

ii. Perbankan Syariah

3) Jurusan Dakwah

Jurusan Dakwah terdiri dari 2 Program Studi yakni :

i. Komunikasi dan Penyiaran Islam

ii. Program Studi Alquran Tafsir

\section{Analisis Strategi Dalam Melaksanakan Kontrol}

\section{Konsep Strategi dalam Melaksanakan Kontrol}

Dalam "Prinsip Manajemen", Harold Koontz mendefinisikan kontrol sebagai: "Tugas manajerial kontrol adalah untuk mengukur dan memodifikasi kinerja bawahan, untuk memastikan bahwa organisasi tujuan dan rencana (dikembangkan untuk mencapai tujuan tersebut) berada di jalankan. JA Stoner menunjukkan: Kontrol adalah kegiatan rutin, di mana hasil yang diharapkan didefinisikan dalam inti dari standar kinerja operasi. Sistem informasi menerima dan dikembangkan juga dan. maka diprediksi dan operasi diimplementasikan 
dibandingkan satu sama lain Perbedaan yang diamati dan penyimpangan dievaluasi dan signifikansi mereka ditentukan. Tindakan korektif penting untuk pencapaian tujuan organisasi dan misi yang diambil di akhir.

Dalam teori manfaat dari sistem pengendalian strategis tampil menarik.Pada kenyataannya ada kesulitan yang cukup besar dalam merancang sistem kontrol strategis yang memenuhi kebutuhan organisasi.Kesulitankesulitan ini kemungkinan akan lebih jelas dalam beberapa jenis bisnis.Dalam keadaan seperti sistem kontrol strategis mungkin harus dirancang dengan mempertimbangkan sifat istimewa yang dihadapi oleh setiap organisasi.Sebagai aturan umum bisa dikatakan bahwa sistem kontrol strategis akan menggunakan nilai yang lebih tinggi di lingkungan bisnis yang stabil atau dewasa dan nilai kurang untuk manajer dalam bisnis yang bergejolak dan berubah dengan cepat.

\section{Laporan Akuntabilitas Kinerja}

Pada kenyataannya, setiap tahun renstra dievaluasi dengan adanya laporan akhir tahun (laptah) dan laporan akuntabilitas kinerja (lakip) sebagai feedback loop ke dalam rencana bergulir (rolling plan). Namun pada praktinya tidak terjadi sistem yang berkesinambungan antara bidang perencanaan dengan bidang evaluasi. Masing-masing hanya berjalan sendiri-sendiri. Sehingga dapat direkomendasikan kolaborasi bidang perencanaan dengan analisis dan evaluasi guna perbaikan yang berkesinambungan diagram alirnya menjadi seperti pada gambar 9.1.

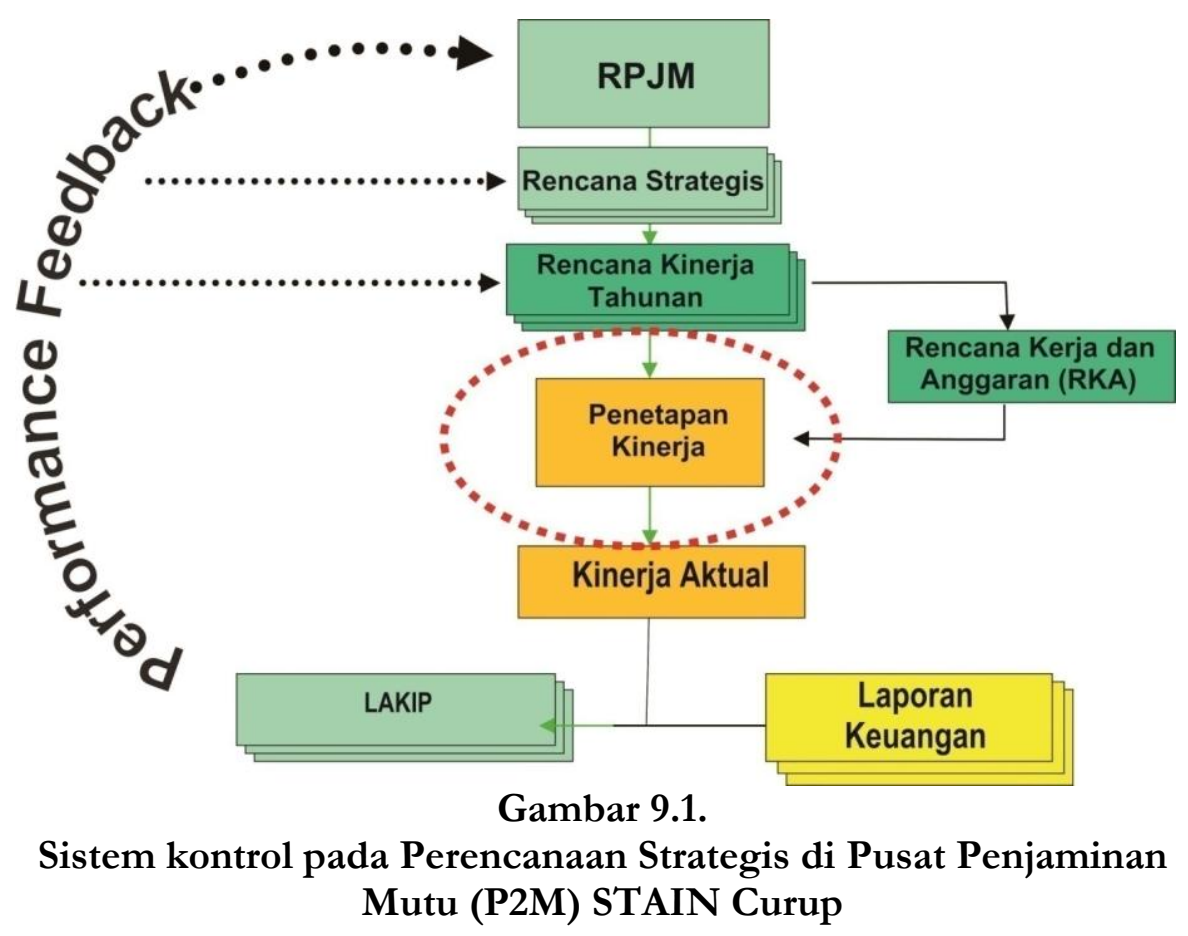


Dalam penerapannya akan sangat mudah jika dibantu dengan teknologi manajemen informasi perkantoran yang terpadu.

Proses perencanaan strategis juga memerlukan manajemen proyek yang baik, mengingat sejak dari proses perencanaan sudah cukup memakan waktu serta pelaksanaannya multi-years (satu rencana jangka menengah dilaksanakan dalam lima rencana jangka pendek), oleh karena itu di dalam satu jangka menengah terjadi overlaping antara kinerja perencanaan dan kinerja pelaksanaan, sehingga untuk ini dibutuhkan pentahapan yang terstruktur dan disiplin secara jadwal dan materi. Komplikasi lebih jauh adalah dalam hal materi perencanaan periode jangka pendek berikutnya, dimana rencana tersebut harus dapat mengakomodasi materi koreksi dari kegagalan/kelemahan rencana jangka pendek sebelumnya.

\section{Analisis Manajemen Perubahan Dan Organisasi Pembelajar}

\section{Konsep Manajemen Perubahan dan Organisasi Pembelajar}

Selama ini, para eksekutif perusahaan kerap menganggap sumber daya manusia dan sumber-sumber daya lainnya sebagai aset berwujud yang dapat dipindah-pindahkan, diganti atau dibuang begitu saja tergantung tuntutan bisnis. Misalnya, rekayasa ulang proses bisnis (business process reengineering) umumnya berakhir dengan downsizing. Manajer semacam ini akan kesulitan memahami perusahaan sebagai aset pengetahuan yang didapat dari orang, proses dan teknologi. Kurangnya wawasan ini bisa menjadi bencana dalam eknomi elektronis yang bergerak cepat di mana leverage terbesar didapat dari aset tak berwujud seperti pengetahuan.

\section{Manajemen Perubahan STAIN Curup}

Kecenderungan pendekatan pada perubahan di STAIN Curup adalah dengan cara, putting in yaitu menempatkan cara dan kebiasaan baru misalnya dengan pemakaian smart board pada presentasi, menggunakan sms centre untuk penyebarluasan informasi, menggunakan mesin presensi dengan sidik jari, dan sebagainya. STAIN Curup dalam pendekatan perubahan cenderung melakukan Creative destruction; yaitu dengan merombak struktur yang tadinya pegawai tidak memiliki job desk yang pasti, diperbaiki dengan jabatan fungsional umum yang sesuai dengan job desk-nya.

STAIN Curup memiliki lima karakteristik manajemen perubahan, yaitu:

a. Systems thinking (Pemikiran Sistem)

Semua dosen dan pegawai harus belajar menyikapi perubahan yang ada di STAIN Curup sebagai bentuk dari reformasi birokrasi.

b. Personal Mastery (Penguasan personal)

Setiap individu didorong untuk memiliki keahlian sesuai dengan minatnya dengan cara mengikutsertakan pada diklat-diklat yang sesuai dengan minat namun juga tetap diperlukan dalam kelangsungan organisasi. 
Seperti diklat, workshop, lokakarya, fotografi, bahasa Inggris, dan sebagainya.

c. Model mental

Kebebasan berpikir dan mengembangkan program serta kegiatan di STAIN Curup telah diterapkan. Hasilnya dapat dilihat pada keberhasilan pelaksanaan program seperti diadakannya diklat bagi dosen di bidang pengajaran, kurikulum, dll dan karyawan di bidang perencanaan dan evaluasi kerja.

d. Membangun visi bersama

Dalam merumuskan visi yang baru dikarenakan visi yang ada akan tidak tepat bila diteruskan, pemimpin menyerahkan perumusan visi pada tim yang dianggap dapat merumuskan dan mewakili cita-cita STAIN Curup. Dengan demikian setiap orang dianggap terlibat dan memiliki rasa memiliki sehingga mau bekerja sama dalam bergotong-royong mewujudkan visi tersebut.

e. Pembelajaran tim

Tim-tim baik dalam kelompok kerja maupun dalam suatu subbidang atau subbagian sudah dibiasakan untuk berpikir bersama, berdialog, saling melengkapi, saling mengoreksi kesalahan. Sehingga diharapkan terjadinya perubahan yang bisa menjadi bagian proses pembaharuan (renewal process) secara keseluruhan. Gagasan yang ingin dilakukan tim terkadang tidak dapat terlaksana karena masalah waktu yang kurang tepat, sehingga pemilihan waktu sangatlah penting.

\section{Kesimpulan}

Dari hasil yang telah diungkapkan pada bagian sebelumnya dapat disimpulkan beberapa hal sebagai berikut :

1. Secara garis besar, proses perencanaan strategis STAIN Curup sudah sistematis dengan menggunakan kerangka pikir dalam proses perencanaannya. Proses perencanaan strategis pada perjalanannya sekaligus mengembangkan indikator kinerja dan target terukur; agar dapat mendefinisikan bagaimana rencana bisa dicapai atau diwujudkan sehingga tidak hanya berhenti pada identifikasi (apa, mengapa, di mana, kapan, dan berapa anggarannya).

2. Dalam penerapan strategi implementasi, STAIN Curup walaupun secara tertulis struktur organisasinya adalah fungsional, namun pada perjalanannya cenderung mengarah ke struktur organisasi matriks karena masing-masing orang dari satu bagian dapat menjadi anggota dari bagian lainnya dan saling membantu.

3. Walaupun memiliki dokumen balanced scorecard, namun dalam praktiknya tidak menggunakan model tersebut dalam mengukur kinerja organisasi. Rencanarencana yang disusun tidak dikaitkan dengan scorecard kinerja organisasi dan individu; hampir tidak mungkin menemukan hubungan yang mengikat antara 
keberadaan sebuah organisasi/individu aparat pemerintah dengan kualitas bagian/penjabaran rencana strategis yang dihasilkannya.

4. Walupun setiap tahun dilakukan evaluasi dengan penyusunan laporan akhir tahun dan laporan kinerja namun tidak berpengaruh terlalu besar dalam memberikan umpan balik.Sehingga dapat dikatakan tidak efektifnya mekanisme untuk pemantauan kinerja organisasi dan pelaporan; masalah ini terutama sebagai akibat tidak ditetapkannya tolok ukur yang mengikat, sebagai bagian yang tidak terpisahkan dari proses perencanaan dan pemuatannya di dalam dokumen rencana. Dalam hal ini budaya subyektif menjadi sangat kental, dan budaya obyektif cenderung punah. Penilaian di atas bersama-sama dengan isu-isu lain yang berhubungan dengan manajemen strategis.

5. Implementasi strategi cenderung merupakan strategi yang emergent karena butuh banyak penyesuaian dan fleksibilitas mengikuti lingkungan yang sedang trend.

\section{Saran}

Pada penyusunan Rencana Strategis yang akan datang, penulis memiliki beberapa rekomendasi yang bisa menjadi bahan pertimbangan, yaitu:

1. Perumusan visi dan misi apabila memiliki rentangan waktu hendaknya memperhitungkan kemampuan organisasi dan ketersediaan sumber daya lainnya.

2. Perlu dievaluasi visi yang ada karena sudah tidak sesuai dengan kondisi sekarang.

3. Balanced score card dapat digunakan untuk perencanaan strategis, manajemen strategis dan evaluasi ke depannya dengan mengembangkan instrument di dalamnya.

4. Penyusunan dokumen perencanaan dan evaluasi dilakukan secara sinergi dengan membuat standar operasional prosedur dalam perencanaan strategis dan evaluasi kinerja sehingga perencanaan berdasar pada hasil evaluasi.

5. Mengembangkan kesatuan antara proses-proses perencanaan, pengelolaan kinerja, dan penganggaran; prinsip dasarnya adalah membiayai keluaran bukan membiayai kegiatan atau proyek.

\section{Daftar Pustaka}

Blatstein, I.M. 2012. Strategic Planning: Predicting or Shaping the Future? Organization Development Journal, Vol. 30 Issues 2, pp. 32

Hill, W.L, Charles and Jones, R. Gareth, 1998. Strategic Management An Integrated Approach, Fourth Edition. Houghton Miflin Company. Boston, New York.

M. Ngalim Purwanto, 2010, Administrasi dan Supervisi Pendidikan, Bandung: Remaja Rosdakarya. 
Mintzberg, Hendry, 1993, Structure in Fives Designing Effective Organizations,Prentice Hall, USA

Thomas dan Hunge David. Strategic Management and Business Policy, New Jersey : Addison Wesley Publ. Company 1990

Renstra Pusat Pengembangan SDM Perhubungan Darat 2010-2014, Jakarta, 2010

Evaluasi Renstra Badan Pengembangan SDM Perhubungan 2010-2014, Jakarta, 2013

Tim Dosen Administrasi Pendidikan Universitas Pendidikan Indonesia, 2012, Manajemen Pendidikan, Bandung: Alfabeta. 
180 | TADBIR : Jurnal Studi Manajemen Pendidikan, Vol. 2, No. 2, Desember 2018

This page belongs to the TADBIR : Jurnal Studi Manajemen Pendidikan TADBIR : Jurnal Studi Manajemen Pendidikan vol. 2 , no. 2, Desember 2018

STAIN Curup - Bengkulu | p-ISSN 2580-3581; e-ISSN 2580-5037 